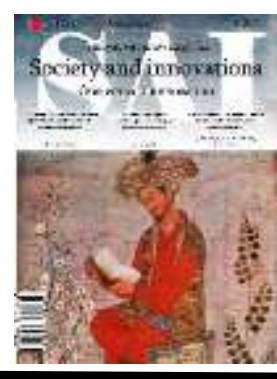

\title{
Evolution and tendencies of formation of the financial market of Namangan region
}

\section{Khadicha KADIROVA ${ }^{1}$}

Institute of Engineering and Technology Namangan, Uzbekistan

\section{ARTICLE INFO \\ Article history: \\ Received January 2021 \\ Received in revised form \\ 15 January 2021 \\ Accepted 20 February 2021 \\ Available online \\ 7 March 2021}

Keywords:
Financial market
Stocks and Bods market
Privatization
Joint-stock companies
Infrastructure of financial
market
Issue
Depository
Stock exchange

\section{Keywords:}

Financial mark

arket

Infrastructure of financial

marke

Depository

Namangan viloyati moliya bozorini shakllantirish evolyutsiyasi va tendensiyalari

\author{
Калит сўзлар: \\ Moliyaviy bozor \\ Aktsiyalar va obligatsiyalar \\ bozori \\ Xususiylashtirish \\ Aktsiyadorlik jamiyatlari \\ Moliya bozori infratuzilmasi \\ Emissiya \\ Depozitariy \\ Fond birjasi
}

\section{ABSTRACT}

The article describes the formation and evolution of the regional financial market. The available prerequisites for its formation, the stages of privatization, the infrastructure of the financial market are considered. The existing problems are identified and the main directions for solving them are worked out.

2181-1415/C) 2021 in Science LLC.

This is an open access article under the Attribution 4.0 International (CC BY 4.0) license (https://creativecommons.org/licenses/by/4.0/deed.ru)

\footnotetext{
${ }^{1}$ Candidate of Economic Sciences, Associate Professor of the Department of Economics and Organization of Industrial Production of the Namangan Institute of Engineering and Technology, Namangan, Uzbekistan E mail: qodirova1472@gmail.com
} 


\section{Эволюция и тенденции формирования финансового рынка Наманганской области}

\author{
Ключевые слова: \\ Финансовый рынок \\ Рынок акций и облигаций \\ Приватизация \\ Акционерные общества \\ Инфраструктура \\ финансового рынка \\ Эмиссия \\ Депозитарий \\ Фондовая биржа
}

\section{АННОТАЦИЯ}

В статье рассматривается становление и эволюция
регионального финансового рынка. Рассмотрены
имеющиеся предпосылки его формирования, этапы
приватизации, инфраструктура финансового рынка.
Выявлены существующие проблемы и выработаны
основные направления их решения.

\section{INTRODUCTION}

The transition of Uzbekistan from a super-centralized planned economic system to a socially oriented market economy has fundamentally changed the nature of social production: property relations, the structure and functioning mechanism of economic entities, forms of financial ties between them, the degree of interest of all sectors of society in the final results of economic activity. The main form of all economic relations, the most important regulator of the process of social reproduction in the republic are commoditymoney relations. The implementation of this trend is inextricably linked with the formation of a developed financial market, which forms the foundation of the economic system of any society and positively affects the pace and quality of the socio-economic transformations taking place in it. The formation of this market in Uzbekistan is based on the principle of phasing, and the transition to each new stage of its formation depends on the emergence of objective structural prerequisites and the reform of the entire economic mechanism both on a sectoral and territorial scale. Thus, the state's strategy aimed at creating an effective financial mechanism is based on the economic potential of the republic, based on an assessment of the real situation, and is aimed at realizing the main goals of the socio-economic development of Uzbekistan. At the same time, the state is taking steps to increase the level of synchronization of economic reform measures in creating competitive domestic segments of this market and phased liberalization of economic activity.

\section{REGION \\ PREREQUISITES FOR THE FORMATION OF THE FINANCIAL MARKET IN NAMANGAN}

The following prerequisites positively affected the pace and quality of the institutional and functional development of the financial market of the Namangan region: expanding the independence of territorial government bodies in resolving issues of socioeconomic development of regions; the formation of a government securities market in the form of a market for state short-term bonds of Uzbekistan; government measures to strengthen the financial condition of commercial banks and the development of the banking services market for legal entities and individuals; the active process of privatization of enterprises in the form of open joint stock companies, the expansion of the issue and circulation of shares of securities of privatized enterprises; targeted support for 
the process of forming a civilized infrastructure of the national securities market, the core of which was the Republican Stock Exchange "Tashkent", the national depository "Vakt", the Agency "Konsauditinform" and others; state support of investment institutions of the stock market and their activities in the securities market through the provision of financial assistance at the stage of their formation; government measures to establish collective financing institutions in the form of privatized investment funds (UIFs). The presence of these prerequisites and favorable factors contributed to the formation of a civilized financial space, the definition of the circle of its main participants, the establishment of financial relations between them and the formation of the infrastructure of the financial market of Namangan region. The process of formation of the financial market in Namangan region, along with trends common to all regions of the republic, had its own characteristics, due to the specific limitations and place of this region in the economy and social life of Uzbekistan.

\section{ANALYSIS OF THE CURRENT STATE OF THE REGIONAL FINANCIAL MARKET}

From the analysis of the formation of the financial market in the Namangan region, it follows that some of its segments, for example, the money market, the credit market, and the insurance services market, had a certain backlog and were in a certain sense developed even before Uzbekistan gained independence. In addition, certain instruments of the government borrowing market in the form of government bonds were circulated here. However, since market relations in the pre-perestroika period were not widespread, and the financial market infrastructure was generally absent, there was no talk of its other segments (stock market, real estate market, mortgage market, derivatives market) as well as the issue of shares, corporate bonds, mortgage certificates, municipal securities and any other modern financial instruments for ownership. Among the factors restraining the formation of the financial market include the protracted process of privatization and privatization, the lack of share ownership in the country, and the underdeveloped financial market infrastructure. The radical changes in the economic mechanism in the Republic of Uzbekistan, which began in the mid-eighties of the XX century, most seriously affected the sphere of formation of financial resources of legal entities and individuals of the Namangan region. The policy taken during this period by the state to reduce budgetary financing of economic bodies, to form a multistructure market economy and introduce elements of market competition in the real sector of the national economy had a positive effect on the pace of institutional formation of the financial market in the region.

In particular, the practice of intra-industry and inter-industry redistribution of funds, which previously undermined incentives to increase production efficiency at the primary level, gradually began to stop. Profit and other available funds of well-functioning enterprises have ceased to be sources of covering losses of low-profitable business entities. At the same time, the volumes of medium-term and long-term loans allocated by banks for business entities were significantly reduced, and control over their intended use was strengthened. At the same time, the negative consequences of the severe structural crisis that Uzbekistan inherited from the command and administrative system continued to affect. The destruction of economic ties, the deterioration of contractual obligations and payment discipline led to disruption of production programs, and hence to the failure to fulfill profit plans. All this ultimately reduced the efficiency of social production and significantly limited the possibilities of self-financing of enterprises. In addition, since the 
mid-80s of the twentieth century. inflationary processes began to develop intensively in the country, negatively affecting the state of the money market, and, consequently, the entire aggregate payment turnover. So, in 1992-1993. the inflation rate in the Namangan region amounted to over 1500 percent per year .

The imbalances and shortcomings in the economic and financial spheres required the intensification of efforts of state, industry, territorial authorities and business entities themselves to form the financial market and its attributes. As a result of measures taken for 1993-1995. The dynamics of the GDP deflator, retail, consumer and wholesale price indices began to show a tendency to a consistent and steady decline. This trend was the result of the implementation of the economic stabilization policy pursued by the Government of the Republic of Uzbekistan, the Ministry of Finance and the Central Bank of the country. Of particular interest is the evolution of the financial market of the Namangan region, which clearly reflects the most characteristic trends in the formation of market relations and the ongoing socio-economic transformations. Although in 1992 only 3 segments functioned in the financial market of Namangan region, as in many other areas of our country (cash and non-cash money market, credit resources market, government loan bond market), its emergence and development is largely connected with trends and features of reforming the entire financial system of the country. After all, it was precisely the specific problems of socio-economic development of Uzbekistan that existed at one time or another that led to the emergence of a specific type of financial instruments, and after them new segments of this market.

Thus, the existing deficit of the state budget in 1991 led to the issuance of the first state security of the Republic of Uzbekistan - the Uzbek winning 12 percent government loan bonds of 1992. The growth of non-payments and receivables contributed to the emergence of transferable bills, and the ongoing privatization of state property to the development of the market corporate securities. One of the most effective means of formation and development of market management methods in the Namangan region was securities that made it possible to mobilize significant amounts of free financial resources of the population and commercial structures for the needs of a radical renewal of the region's economy.

Securities fixing the right to capital, allowed to redistribute the property of state enterprises into the property of joint-stock companies, i.e. private owners, thereby increasing the effectiveness of its management and freeing the state from functions unusual for it.

The adoption of the Law of the Republic of Uzbekistan "On Securities and Stock Exchange" on September 2, 1993 laid the foundation for the creation of a securities market in the regions, as it regulated the issuance of five types of securities, determined the legal basis for the creation and operation of stock exchanges and some others securities market participants. [1] It is the securities market that has become one of the most powerful mechanisms for introducing the principles of a market economy, an effective means of deeply reforming property relations, forming qualitatively new sources of economic growth, concentration and redistribution of investment resources. With the beginning of the mass privatization and corporatization of state enterprises, in essence, a new direction was identified for the development of the regional stock market - state enterprises that were newly formed or privatized in the form of joint-stock companies became the first issuers of shares, laying the foundation for the corporate securities market. 
The refusal in the republic of the idea of voucher privatization, which is being introduced in a number of CIS countries, made it possible to mobilize considerable financial resources to support privatized enterprises in the most difficult postprivatization period for them. In addition, part of the proceeds from privatization was aimed at creating the infrastructure of the financial market of the region.

In March 1994, the region embarked on a broad involvement of the population in the process of privatization and privatization and the formation of joint stock companies with a simultaneous reduction in the share of shares owned by the state. Many of the established closed joint stock companies were transformed into open joint stock companies, which increased the transparency of the stock space and the activity of small and medium investors on it.Subsequently, in the Namangan region, the process of forming a regional infrastructure of the stock market began, which includes a branch of the Republican Stock Exchange "Tashkent", an extensive network of investment institutions, including independent second-tier depositories, investment and privatized funds (IFs), brokerage houses and investment companies, registrars, investment advisors, etc.

At the same time, regional branches of the National Depository "VAKT", the Agency "Konsauditinform", the Center for Information and Analytical Support of Stock Market Participants "Tahlil Ahborot Markaz", and the State Investment Firm "Davinkom" began to open here. [2] The increase in sales volumes of privatized enterprises was a condition not only for the formation of a real class of owners, but also for "instilling a taste" in entrepreneurship, for shareholders to recognize their rights and opportunities. The development of the securities market in the Namangan region was facilitated by the adoption in April 1996 of the Laws of the Republic of Uzbekistan "On Joint-Stock Companies and the Protection of Shareholders' Rights" and "On the Mechanism of the Operation of the Securities Market", which streamlined the privatization process and the activities of joint-stock enterprises[3].In July 1998, regional offices of two new infrastructure institutions began to function on the regional securities market: the ElsisSavdo electronic off-exchange trading system and the Elsis-Clearing Settlement and Clearing House, designed to serve OTC bidders. Their creation markedly intensified the work of the regional stock market, contributed to the influx of investment resources into the real sector of the regional economy, as well as increased income of domestic and foreign investors owning securities of issuers in this region.

\section{REGION \\ ANALYSIS OF PRIVATIZATION PROCESSES IN UZBEKISTAN AND NAMANGAN}

The transfer of the economy of Uzbekistan to market relations has necessitated the privatization process, since privatization is the objectively necessary process characteristic of countries implementing progressive political, economic and social transformations. The privatization process in Uzbekistan began with the adoption of the Law on Denationalization and Privatization in November 1991. [4] It was somewhat different from the privatization processes of a number of countries. One of the main differences was that privatization was carried out in stages, had a targeted focus, and was also aimed at after privatization support and development of entrepreneurship. The phased privatization in Uzbekistan can be defined as: the stage of small privatization (1992-1993), during which the targeted orientation of privatization was shown - this is the process of housing privatization. The possibility of redemption by members of labor 
collectives of the repurchase of the shares of their enterprises on preferential terms, as well as the preferential procedure for privatizing the property of state farms by collectives of agricultural enterprises; the stage of large-scale privatization (1994-1998), characterized by the massive transfer of enterprises to joint-stock companies; a stage characterized by the definition of a list of objects not subject to privatization (early 1998), which continues to this day. Currently, the process of privatization of almost all facilities and enterprises not included in this list is ongoing. Consider several periods of the last stage of privatization. In the first half of 2004 alone, 660 manufacturing enterprises and social facilities were transformed into non-state forms of ownership, which is $94.6 \%$ compared to the same periods of the previous year.

Table 1. Non-state enterprises created during the privatization process.

\begin{tabular}{|l|l|l|l|l|l|l|l|}
\hline \multirow{2}{*}{ Periods } & \multirow{2}{*}{ Total } & \multicolumn{3}{|l|}{ Including } \\
\cline { 3 - 7 } & & \multicolumn{5}{|l|}{ Join-stock companies } & \multicolumn{2}{l|}{$\begin{array}{l}\text { Limited liability } \\
\text { companies }\end{array}$} & $\begin{array}{l}\text { Private } \\
\text { enterprises }\end{array}$ \\
\cline { 3 - 8 } & & Unit & $\begin{array}{l}\text { The lot. } \\
\text { weight } \\
(\%)\end{array}$ & Unit & $\begin{array}{l}\text { The lot. } \\
\text { weight } \\
(\%)\end{array}$ & Unit & $\begin{array}{l}\text { The lot. } \\
\text { weight } \\
(\%)\end{array}$ \\
\hline $\begin{array}{l}2003 \\
\text { year }\end{array}$ & 643 & 24 & 3,7 & 63 & 9,8 & 556 & 86,5 \\
\hline $\begin{array}{l}2004 \\
\text { year }\end{array}$ & 660 & 13 & 2,0 & 102 & 15,5 & 527 & 79,8 \\
\hline
\end{tabular}

The relatively low specific weight in those years of the share of joint-stock companies is explained by the fact that only enterprises whose authorized capital is equivalent to at least 50 thousand US dollars are converted into joint-stock companies. The sale of privately owned state and previously unallocated blocks of shares of a large number of previously privatized enterprises, including using new mechanisms for the sale of state assets, continued. In the sectoral category, most of the enterprises in the oil and gas industry (61), public education (61), agriculture and water management (58), healthcare (37) were privatized, and in the territorial breakdown of enterprises in Tashkent (124), Fergana (73) Surkhandarya (58) and Syrdarya (53) regions. It should be noted that the share of joint-stock companies in the total number of created non-state enterprises in 2003-2004 was low compared with the established limited liability companies and private enterprises. The trend towards a decrease in the total number of AO continued in subsequent years (chart No. 1). But at the same time, it should be noted that the growth of AO emissions has a tendency to increase. The number of managers of AOs with the state share of shares transferred to trust management also decreased (chart No. 3) from 2948 pcs. in 2000 up to 958 pcs. in 2005, and if we consider the structure of trust management, trust attorneys occupy a greater share here - their trusts were $85.5 \%$ in 2000, by 2005 this trend remained at the level of $86.3 \%$. Since 2004 , confidence has appeared in management companies and their number has increased from 13 units. in 2004 to 71 units. - in 2005.The implementation of the state property privatization program continued (chart No. 4), by 2008, there were 121 units left for enterprises where the state share of the property was retained, -1269 units were fully sold for sale, 105 units were sold at zero 
cost, and others. The goal of introducing enterprise implementations at zero cost was to preserve the enterprise's activities while attracting these investments and creating jobs.

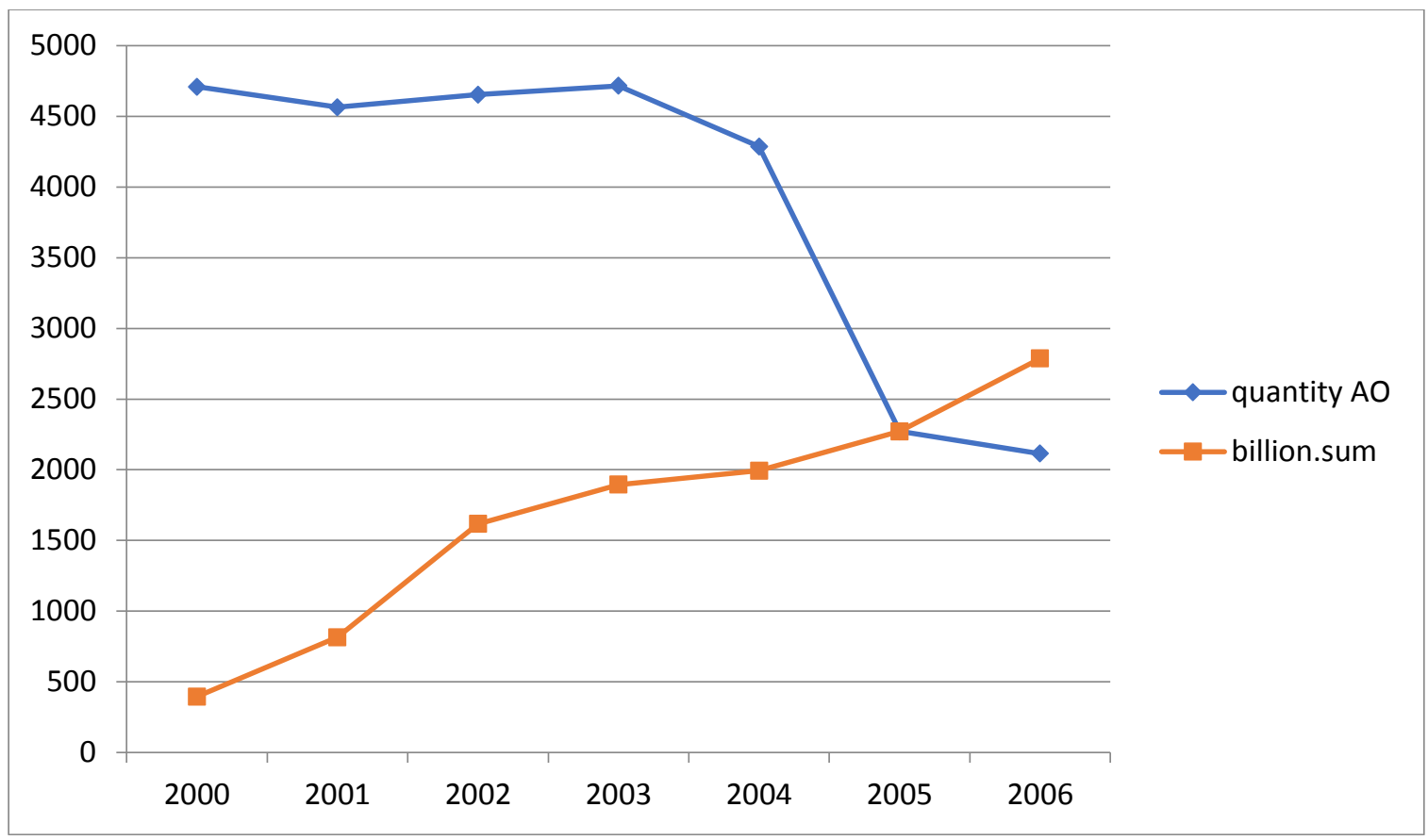

Chart 1. Dynamics of changes in the total number of AO and their envelopes of emission for 2000-2006

The dynamics of changes in the number of business entities with a state share of ownership is also prone to decrease (chart No. 2).

Dynamics of changes in the number of economic entities from the state aid of shares

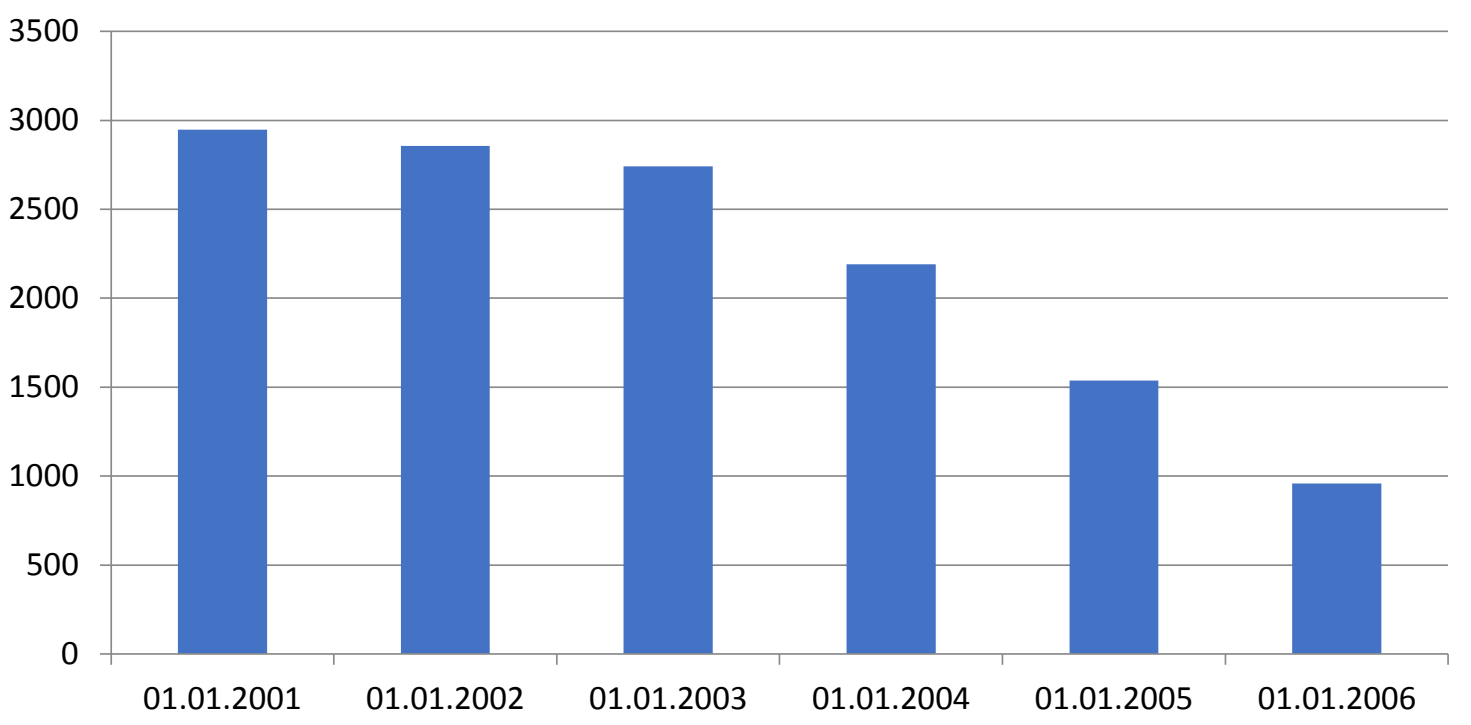

Chart 2. The diagram shows their number decreased from 2948 pcs. in 2000 to -958 pcs. in 2005. 


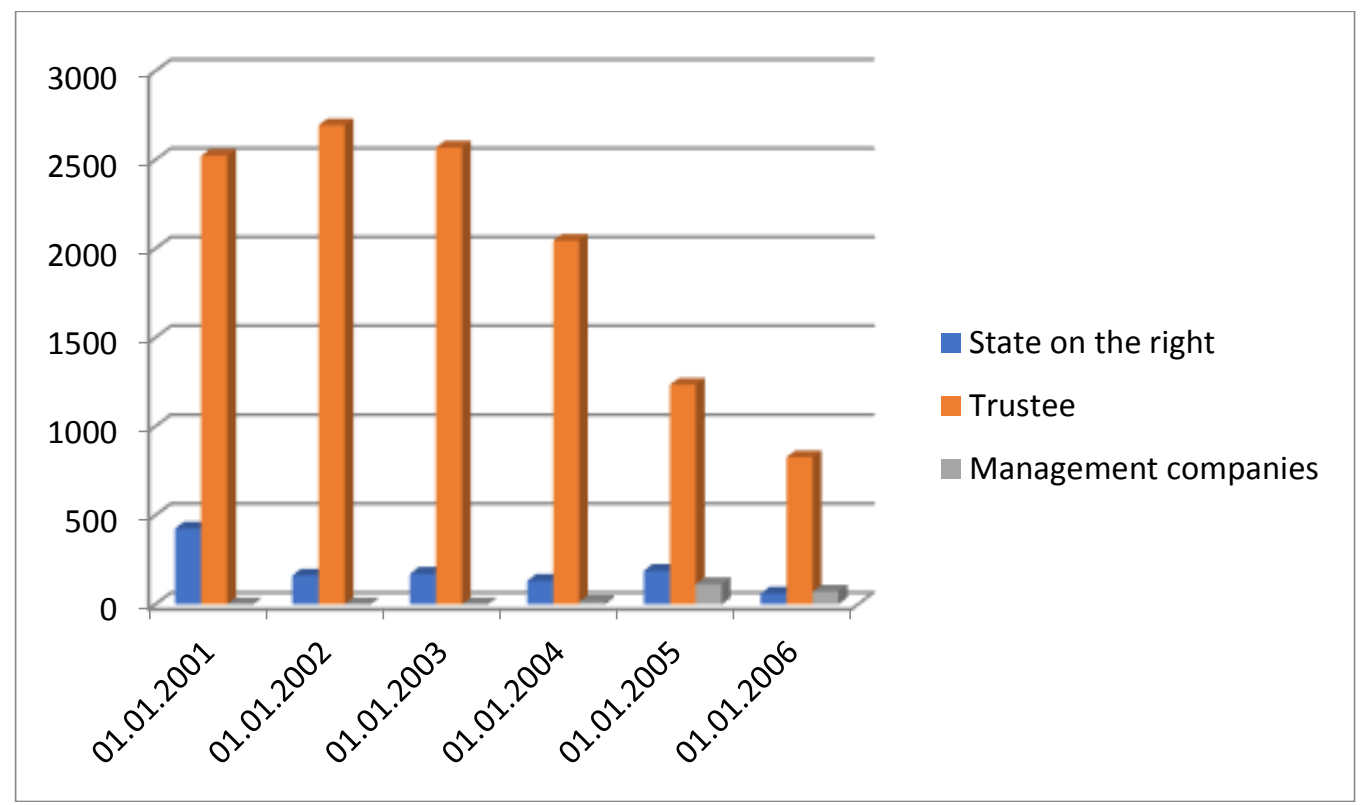

Chart 3. The number of AO managers with state shares transferred to trust for 2001-2006

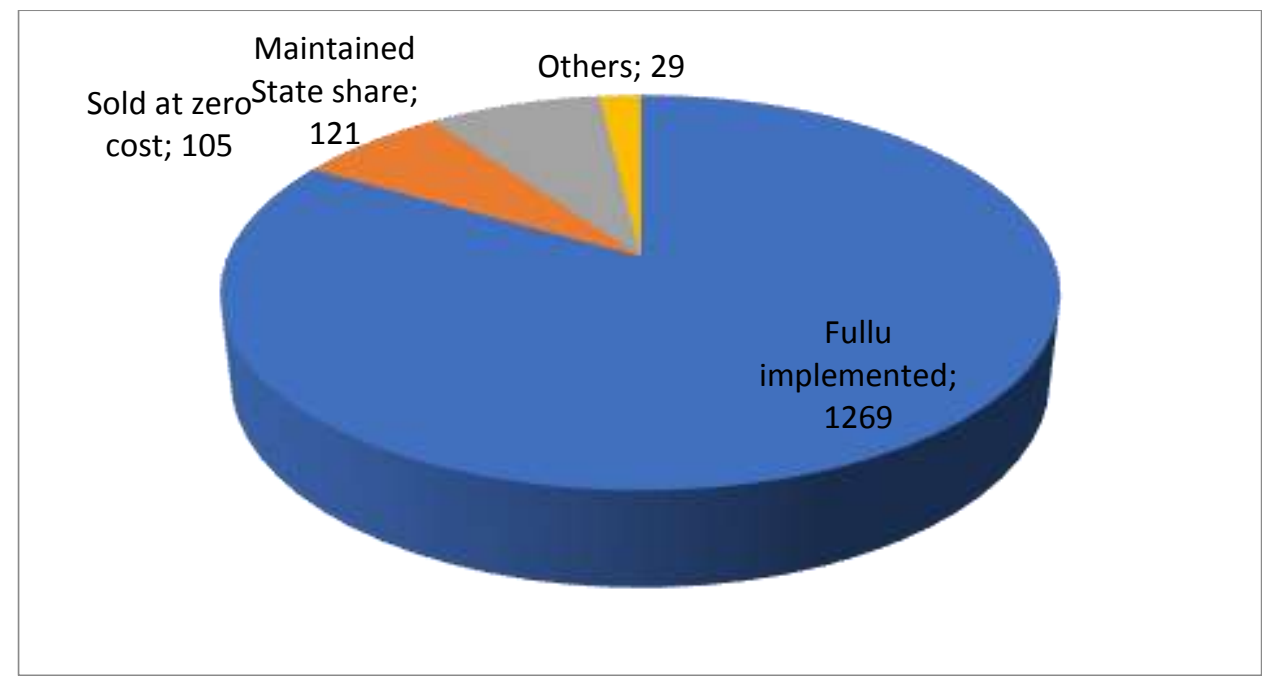

Chart 4. Results of the implementation of the state property privatization program for 2006-2008

Data on the number of joint-stock companies having a state share of shares for 2000 - 2006 can be considered in chart No. 5 . 
Chart 5.Data on the number of joint stock companies having a state share for 2000-2006

\begin{tabular}{|c|c|c|c|c|c|c|c|c|c|c|c|c|c|c|}
\hline \multirow[b]{2}{*}{ Indicators } & \multicolumn{2}{|c|}{01.01 .2000} & \multicolumn{2}{|c|}{01.01 .2001} & \multicolumn{2}{|c|}{01.01 .2002} & \multicolumn{2}{|c|}{01.01 .2003} & \multicolumn{2}{|c|}{01.01 .2004} & \multicolumn{2}{|c|}{01.01 .2005} & \multicolumn{2}{|c|}{01.01 .2006} \\
\hline & $\begin{array}{c}\text { Quantity } \\
\text { AO }\end{array}$ & $\begin{array}{l}\text { billion. } \\
\text { Sum }\end{array}$ & $\begin{array}{c}\text { Quantity } \\
\text { AO }\end{array}$ & $\begin{array}{l}\text { billion. } \\
\text { Sum }\end{array}$ & $\begin{array}{c}\text { Quantity } \\
\text { AO }\end{array}$ & $\begin{array}{l}\text { billion. } \\
\text { Sum }\end{array}$ & $\begin{array}{c}\text { Quantity } \\
\text { AO }\end{array}$ & $\begin{array}{l}\text { billion. } \\
\text { Sum }\end{array}$ & $\begin{array}{c}\text { Quantity } \\
\text { AO }\end{array}$ & $\begin{array}{l}\text { billion. } \\
\text { Sum }\end{array}$ & $\begin{array}{c}\text { Quantity } \\
\text { AO }\end{array}$ & $\begin{array}{c}\text { billion. } \\
\text { Sum }\end{array}$ & $\begin{array}{c}\text { Quantity } \\
\text { AO }\end{array}$ & $\begin{array}{c}\text { billion. } \\
\text { Sum }\end{array}$ \\
\hline $\begin{array}{l}\text { Total joint } \\
\text { stock } \\
\text { companies } \\
\text { and their } \\
\text { emissions }\end{array}$ & 4709 & 394,90 & 4555 & 815,30 & 4654 & $\begin{array}{c}1 \\
617,10\end{array}$ & 4716 & $\begin{array}{c}1 \\
895,60\end{array}$ & 4287 & $\begin{array}{c}1 \\
993,90\end{array}$ & 2271 & $\begin{array}{c}2 \\
217,70\end{array}$ & 2114 & $\begin{array}{c}2 \\
787,30\end{array}$ \\
\hline $\begin{array}{l}\text { The number } \\
\text { of AO with } \\
\text { state assets, } \\
\text { incl }\end{array}$ & 3123 & 289,90 & 3109 & 652,90 & 3187 & $\begin{array}{c}1 \\
413,90\end{array}$ & 3074 & $\begin{array}{c}1 \\
623,40\end{array}$ & 2319 & $\begin{array}{c}1 \\
659,70\end{array}$ & 1170 & $\begin{array}{c}1 \\
810,40\end{array}$ & 1036 & $\begin{array}{c}2 \\
325,10\end{array}$ \\
\hline $\begin{array}{c}\text { State share } \\
\text { held by the } \\
\text { state }\end{array}$ & 3000 & 4,50 & 2869 & 159,40 & 2591 & 841,90 & 2406 & 857,00 & 1631 & 876,00 & 402 & $\begin{array}{c}1 \\
013,50\end{array}$ & 290 & $\begin{array}{c}1 \\
014,80\end{array}$ \\
\hline $\begin{array}{l}\text { Government } \\
\text { assets to be } \\
\text { sold }\end{array}$ & 785 & 33,80 & 945 & 308,00 & 1205 & 350,20 & 1119 & 460,10 & 837 & 486,00 & 566 & 506,30 & 420 & 766,90 \\
\hline $\begin{array}{l}\text { Including } \\
\text { unredeemed } \\
\text { share of the } \\
\text { labor } \\
\text { collective }\end{array}$ & 418 & 1,00 & 184 & 20,60 & 173 & 17,70 & 191 & 15,90 & 120 & 5,80 & 76 & 1,50 & 48 & 1,90 \\
\hline $\begin{array}{l}\text { State assets } \\
\text { transferred } \\
\text { to the } \\
\text { authorized } \\
\text { fund of } \\
\text { business } \\
\text { associations }\end{array}$ & 283 & 1,60 & 245 & 85,50 & 1203 & 221,80 & 789 & 306,30 & 654 & 297,70 & 567 & 290,50 & 586 & 543,40 \\
\hline
\end{tabular}


Continuing a retrospective analysis of the quantity, structure of capital and the volume of emissions of joint stock companies for 2012-2016. (table No. 2,3), we are considering a trend towards a decrease in the total number of AOs from 1232 units. in 2012 to - 615 units. in 2017. A decrease is also observed in the structural plan, the share of state property and business entities is decreasing, but at the same time, the share of foreign investors in 2015 was 334 units, 2016 - 309 units, 2017 - 319 units.

2-Table Information on the structure and number of joint stock companies.

\begin{tabular}{|c|c|c|c|c|c|}
\hline Indicators & 2013year & 2014 year & 2015 year & 2016 year & 2017 year \\
\hline $\begin{array}{c}\text { The number of } \\
\text { A0 (pieces) }\end{array}$ & 1232 & 1090 & 717 & 631 & 615 \\
\hline $\begin{array}{c}\text { With a share of } \\
\text { state ownership } \\
\text { (pieces) }\end{array}$ & 424 & 395 & 241 & 170 & 174 \\
\hline $\begin{array}{c}\text { With a share of } \\
\text { business entities } \\
\text { (pieces) }\end{array}$ & 456 & 445 & 294 & 283 & 269 \\
\hline $\begin{array}{c}\text { With a share } \\
\text { without business } \\
\text { entities } \\
\text { (pieces) }\end{array}$ & 500 & 392 & 237 & 178 & 219 \\
\hline $\begin{array}{c}\text { With a share of } \\
\text { foreign investors }\end{array}$ & - & - & 334 & 309 & 319 \\
\hline $\begin{array}{c}\text { With a share of } \\
\text { foreign investors } \\
\text { of 15 percent or } \\
\text { more (units) }\end{array}$ & - & - & 87 & 179 & 172 \\
\hline
\end{tabular}

The trend of increasing emissions over the years also remains.

Tabel 3.

The capital structure of joint stock companies

Republic of Uzbekistan for 2012-2016

\begin{tabular}{|c|c|c|c|c|c|c|}
\hline Indicators & Unit & 2012year & 2013 year & 2014 year & 2015 year & 2016 year \\
\hline $\begin{array}{c}\text { Volume of } \\
\text { issues } \\
\text { (circulating } \\
\text { shares) }\end{array}$ & $\begin{array}{c}\text { Billion } \\
\text { sums }\end{array}$ & 9111,48 & 10249,37 & 12725,58 & 16472,85 & 30463,50 \\
\hline $\begin{array}{c}\text { Share in } \\
\text { GDP }\end{array}$ & Percent & 2,14 & 0,81 & 0,92 & 2,05 & 7.25 \\
\hline $\begin{array}{c}\text { Gos. share } \\
\text { in the total } \\
\text { volume of } \\
\text { share issues }\end{array}$ & Percent & 53,42 & 55,00 & 56,33 & 60,59 & 73,01 \\
\hline $\begin{array}{c}\text { Share of } \\
\text { households } \\
\text { in the total } \\
\text { volume of } \\
\text { share issues }\end{array}$ & Percent & 12,93 & 11,85 & 10,10 & 12,63 & 11,34 \\
\hline
\end{tabular}


One of the fundamental directions of economic reforms is the formation of an effective multistructure economy, the deepening of privatization processes and the formation of a real competitive environment. An effective and final solution to property issues is the most acute and significant in the system of measures to create a market economy both at the first and second stages of economic reforms, and in the further development of our republic. An important task in the republic was the elimination of the monopoly of state ownership and the creation of various forms of ownership. This, in turn, led to the process of denationalization and privatization in the country. Denationalization and privatization, being an integral part of the system of measures to enter the market, should have been carried out in stages, taking into account real preparedness for them, the interests of the labor collectives themselves, with the indispensable observance of the principles of social justice.

Reform of state-owned enterprises in general, and corporatization in particular, is part of a package of broader reforms aimed at achieving the interconnected goals of stabilization and structural transformation. Given that many unprofitable enterprises were in state ownership, privatization is considered necessary to establish firm financial discipline at enterprises during the stabilization period. Regarding structural issues, the privatization or transformation of state-owned enterprises into a joint-stock company is probably the only way to quickly introduce private property rights: it also opens up prospects for establishing effective corporate control over the enterprise. As of 01.01.2020, we can consider the regional sectoral structure of enterprises with state ownership and by district as of 01.01.2020 according to table No. 4 .

Table 4.

Information about enterprises with state ownership in the Namangan region as of 01.01.2020.

\begin{tabular}{|c|c|c|c|c|c|c|c|c|c|c|}
\hline \multirow[b]{2}{*}{ № } & \multirow[b]{2}{*}{$\begin{array}{l}\text { City and } \\
\text { regions }\end{array}$} & \multirow[b]{2}{*}{$\begin{array}{c}\text { Prep } \\
\text { with } \\
\text { stat } \\
\text { e } \\
\text { debt }\end{array}$} & \multicolumn{8}{|c|}{ Including by industry } \\
\hline & & & $\begin{array}{l}\text { Infor } \\
\text { tech } \\
\text { and } \\
\text { commu } \\
\text { nes }\end{array}$ & $\begin{array}{l}\text { Kom } \\
\text { neg, } \\
\text { builds } \\
\text { and } \\
\text { rende } \\
\text { red } \\
\text { servic } \\
\text { es }\end{array}$ & $\begin{array}{c}\text { Har } \\
\text { d } \\
\text { Pro } \\
\text { m } \\
\text { and } \\
\text { Fina } \\
\text { nce }\end{array}$ & $\begin{array}{c}\text { Lay } \\
\text { dow } \\
\text { n } \\
\text { pro } \\
\text { m } \\
\text { mas } \\
\text { h } \\
\text { syst } \\
\text { em } \\
\text { and } \\
\text { elect } \\
\text { roni } \\
\text { cs }\end{array}$ & $\begin{array}{l}\text { SOC, } \\
\text { touris } \\
\text { m and } \\
\text { pharm } \\
\text { acist }\end{array}$ & $\begin{array}{l}\text { Nefteg } \\
\text { az, } \\
\text { chemi } \\
\text { cal } \\
\text { indust } \\
\text { ry }\end{array}$ & $\begin{array}{c}\text { ag } \\
\text { ric } \\
\text { ult } \\
\text { ur } \\
\text { al } \\
\text { an } \\
\text { d } \\
\text { fo } \\
\text { od } \\
\text { pr } \\
\text { o } \\
\text { m }\end{array}$ & $\begin{array}{l}\text { Prom } \\
\text { zone } \\
\text { invest. }\end{array}$ \\
\hline 1. & $\begin{array}{c}\text { Namangan } \\
\text { city }\end{array}$ & 67 & 5 & 37 & 3 & 2 & 15 & - & 3 & 2 \\
\hline 2. & $\begin{array}{l}\text { Kosonsoy } \\
\text { region }\end{array}$ & 4 & & 3 & & & & & & 1 \\
\hline
\end{tabular}




\begin{tabular}{|c|c|c|l|c|c|c|c|c|c|c|}
\hline 3. & $\begin{array}{c}\text { Mingbulaq } \\
\text { region }\end{array}$ & 6 & 4 & & & 1 & & 1 & \\
\hline 4. & $\begin{array}{c}\text { Namangan } \\
\text { region }\end{array}$ & 7 & & 5 & & & & & 2 & \\
\hline 5. & $\begin{array}{c}\text { Narin } \\
\text { region }\end{array}$ & 8 & & 5 & & & 2 & & & 1 \\
\hline 6. & Pop region & 12 & & 9 & & & 1 & & 1 & 1 \\
\hline 7. & $\begin{array}{c}\text { Turakurgan } \\
\text { region }\end{array}$ & 11 & & 8 & & & 1 & & 1 & 1 \\
\hline 8. & $\begin{array}{c}\text { Uychi } \\
\text { region }\end{array}$ & 5 & & 4 & & & 1 & & & \\
\hline 9. & $\begin{array}{c}\text { Uchkurgan } \\
\text { region }\end{array}$ & 6 & & 4 & & & 1 & & 1 & \\
\hline 10. & $\begin{array}{c}\text { Chartaq } \\
\text { region }\end{array}$ & 9 & & 5 & & & 1 & & 3 & \\
\hline 11. & $\begin{array}{c}\text { Chust } \\
\text { region }\end{array}$ & 10 & & 7 & & & 1 & & & 2 \\
\hline 12. & $\begin{array}{c}\text { Yangikurga } \\
\text { n region }\end{array}$ & 9 & & 6 & & & 1 & & 2 & \\
\hline & Total & $\mathbf{1 5 4}$ & $\mathbf{5}$ & $\mathbf{9 7}$ & $\mathbf{3}$ & $\mathbf{2}$ & $\mathbf{2 5}$ & $\mathbf{0}$ & $\mathbf{1 4}$ & $\mathbf{8}$ \\
\hline
\end{tabular}

Analyzing the higher table on enterprises with state ownership in the Namangan region as of 01.01.2020, it can be noted that of the total number of enterprises, the largest indicator of enterprises with state ownership in the sectors is in the utilities, construction and services - 97 enterprises (63\%), the next place is occupied by 25 enterprises (16.2\%) - social industries, tourism and pharmaceuticals, 14 enterprises (9\%) - agriculture and the food industry and scanty shares - 8, 5, 3, 2 units $(5.2 \%, 3.2 \%, 1.9 \%, 1.3 \%)$-industrial zones and investment, information technology and communications, heavy industry and finance, light industry, mechanical engineering and electronics, respectively[5]

\section{CONCLUSION AND OFFERS}

Analyzing the foregoing, the following conclusions can be drawn. The privatization processes in the region are continuing, and there is a tendency to further sell the share of state property, both directly to the buyer with a certain set value, and at zero cost, with the condition of attracting the established volumes of investments and creating jobs at the enterprise.

Meanwhile, further scale-up and attractiveness of the financial market of Namangan region depend not only on the efficiency of the banking services market and the securities market, but also on the pace and synchronization of the development of its segments and the expansion of the use of new financial instruments. To use the reserves of growth in the financial market of the region, it is necessary to consolidate the efforts of republican, sectoral and regional government bodies, as well as business circles and the public of the whole region.

As an analysis of foreign experience shows, the pace and quality of the formation of regional financial markets, along with macroeconomic factors, are greatly influenced by organizational, managerial and functional-technical factors related to the level of development of investment and financial infrastructure. The most important of them, 
determining the level of infrastructure support for participants in regional financial markets, include:

- informational transparency of issuers and consumers of financial resources;

- the degree of information transparency of various sectors of the financial market;

- the level of organization and equipment of trading and clearing and settlement systems both on the exchange and over-the-counter markets;

- the availability and reliability of transactions with different types of financial instruments by large and small consumers of financial resources;

- the level of development of the range and quality of services for the storage of securities, accounting for property rights to them, as well as their re-registration;

- the quality and reliability of the organization of insurance of financial market participants and various financial transactions;

- providing guarantees to protect the rights and legitimate interests of small and medium investors.

Assessing precisely from these positions the current state of infrastructure services for participants in the financial market of the Namangan region, it is necessary to recognize the insufficiently high level of development of the investment and financial infrastructure of this region. Therefore, it is necessary to solve the issue of opening a wide network of leasing, factoring and managing investment companies, consulting, underwriting and transfer agent firms, rating and real estate agencies, stock, insurance and legal centers, etc. in the region. An important element of the formed regional investment and financial infrastructure should be territorial stock centers, in the structure of which it is advisable to open marketing departments of regional financial markets, with which you can monitor the process of their institutional and functional development, monitor the flow of capital between different sectors of the economy and direct investment of temporarily free funds of the population in financial instruments of the most competitive issuers. Thus, work to create a branched investment and financial infrastructure, designed not only to provide technical assistance to its main participants in the issuance and circulation of financial instruments, but also to insure commercial risks associated with them, should be the most important direction of the institutional development of the regional financial market. The presented analysis of the current state, existing problems and perspective directions of development of the financial market of the Namangan region indicates the need to expand the powers of local authorities in pursuing an active regional policy in the field of institutional support for the formation of the financial market.

The first step towards the implementation of this complex task should be the creation and legislative support of the State concept for the formation and development of regional financial markets, which should subsequently form the basis of the State program for reforming the regional economy of Uzbekistan. In terms of its scale and complexity, this program should be adequate to the program of privatization and privatization of state property, adopted in the early 90 s of the last, twentieth, century. Another effective way to increase the role of local authorities in resolving this issue should be to expand their capabilities in providing financial support for the institutional formation of regional financial markets. Given that many territorial authorities, due to financial constraints, cannot yet fully rely on the local budgets of their regions, they need to be given the right to use additional sources of revenue for local budgets for the needs of establishing a financial market. In our opinion, the fundamental condition for pursuing an effective institutional 
policy for the development of regional financial markets is the creation, under the regional khokimiyats of the republic, of specialized departments for the development of financial markets and attracting investments with the provision of appropriate powers and levers of influence on business entities.

The issues of improving the efficiency of the use of financial instruments also remain relevant at the current stage of the development of the national economy, as one of the prospects for the development of the national financial market should be its entry into the international arena. According to the Russian Export Center (REC), the securities market is an industry that is not yet integrated into foreign markets, and, in particular, the Russian capital market, but could become a new direction for cooperation between entrepreneurs of both countries [6].

The main tasks of the institutional units created in the structure of local authorities should be:

- development of strategic programs for the development of various segments of the financial market, as well as the necessary infrastructure for them;

- improving the mechanism for attracting domestic and foreign investments for the needs of regional development;

- making proposals to higher authorities on the development of regulatory documents stimulating the development of regional financial markets;

- implementation of operational activities on modern institutional and functional support of the process of formation of financial markets in the regions. [7]

Active inclusion of institutional units in the process of establishing regional financial markets will increase the pace and improve the quality of economic and social transformations being carried out in the regions of Uzbekistan. As international practice shows, trust in the regional financial market, investment inflows for the development of the territory, ensuring transparency of financial transactions, as well as protecting the rights and interests of all market participants are achieved through effective regulation of various aspects of financial activity and constant monitoring of its subjects. Thus, in total, 1,113 cases were considered on bankruptcy issues in the region by regional economic courts: out of 375 enterprises declared bankrupt in 2018 and did not complete bankruptcy proceedings in 2019, 738 enterprises declared bankrupt on January 1, 2020. Out of 375 enterprises - 374 were removed from the state register, 1 enterprise continues bankruptcy proceedings. Out of 738 enterprises, 252 completed bankruptcy proceedings and were removed from the state register. During the reporting period, a total of 626 enterprises were removed from the state register. Of these, 33 enterprises by court decision continue their activities as a result of financial recovery. Currently, bankruptcy proceedings are ongoing in 487 enterprises. Of the 28 claims submitted to the judicial authorities in 2019: 5- satisfied, 6- rejected, 8- relatively satisfied, 5-completed, 2- not approved, 2- considered. As a defendant, 20 claims were submitted, of which 2 were fully satisfied, 14 were rejected, 3 were not considered, and 1 process was completed.

The most common violations in common practice are the lack of information about issuers and securities, or its untimely publication, untimely provision of reports or information to state supervisory authorities; incorrect maintenance of the register of shareholders; untimely or incomplete payment of dividends, as well as failure to publish in the media announcements on holding general meetings of shareholders and the annual report of the company; holding them without a quorum; lack of work plans for the 
development and reconstruction of enterprises. In many joint-stock companies, the income received is poorly monitored in the part intended for reservation due to the accumulation of dividends on the state share of shares and their subsequent use for their intended purpose. The heads of individual joint-stock companies do not ensure compliance with the requirements of the legislation on auditing, monitoring the movement of shares and payment of dividends, are passive in the implementation of the second and subsequent share issues. From this it follows that one of the most important areas of increasing the effectiveness of control, coordination and supervision of financial market participants is the improvement of the regulatory framework governing the activities and relations of its participants. Correct and timely regulation of financial activities with the help of flexible legislation that can create fair rules for the game on the stock space and monitor their compliance with all market participants is a prerequisite for the sustainable development of any regional financial market.

In the Namangan region at the end of the 90s of the XX century there was a tendency to move from direct state regulation of financial activities to a form of regulation that involves the transfer of some of its functions to the participants in this market, united in self-regulatory organizations of professional participants in the financial market (SRO). The first such organization was the Namangan regional branch of the Association of Banks of Uzbekistan, opened in 1998, followed by another self-regulatory organization, the National Association of Investment Institutions (NAII), in 2000, uniting all investment institutions operating in the regional stock market.

The purpose of the SRO was to assist its members in the implementation of their professional activities, to protect their legal rights and to represent their interests in the legislative and executive authorities. The effective functioning of self-regulatory organizations in each of the areas of professional activity in the regional financial market should make it possible to develop detailed requirements and standards for their participation in the market, provide tighter control over their possible violations, and therefore create the conditions for competent regulation of the activities of professional participants in the financial market. [8]

Timely formation in the region of a two-tier system of regulation of the financial market, based on a combination of state regulation and self-regulation, will achieve optimal market management and ensure the necessary level of protection of the rights and interests of all its participants. In addition to this effect, due to the effective interaction of the state with self-regulatory organizations, prices will decrease every year due to a reduction in the time and financial resources of professional market participants in connection with the timely implementation of regulatory requirements. [9]

The successful implementation of the indicated directions of the institutional development of the financial market of the Namangan region will undoubtedly affect the quality of work of its main participants, will contribute to the implementation of consistent reforms in the sphere of money circulation and credit, ensuring the creation of a developed, competitive and stable financial and credit environment conducive to the development of investment processes and economic growth, strengthening the competitiveness of business entities and increasing living standards listening to the population of the region. 


\section{REFERENCES}

1. The Law of the Republic of Uzbekistan "On Securities and Stock Exchange" dated (02.09.93). New laws of Uzbekistan. Tashkent: Adolat.

2. Decree of the President of the Republic of Uzbekistan "On Additional Measures for the Development of the Securities Market" dated September 7, 1995 // New laws of Uzbekistan. Tashkent: Adolat.

3. Decree of the President of the Republic of Uzbekistan "On the establishment of a Center for the coordination and control of the functioning of the securities market under the State Property Committee of the Republic of Uzbekistan" (26.03.1996). New laws of Uzbekistan. Tashkent: Adolat.

4. The Law of the Republic of Uzbekistan "On Denationalization and Privatization" (11/19/91). New laws of Uzbekistan. Tashkent: Adolat.

5. Statistical data of the Namangan Regional Agency for State Asset Management for 2019.

6. Butikov I. L. "Conceptual directions of integration of the securities market of Uzbekistan in foreign and international capital markets" Abstracts of the international conference of the BFA R. Uz. 2019. https://research-center.uz/reports/2019/.

7. Ph.D., Assoc. Kadirova H.T.Namangan Engineering and Technology Institute, Uzbekistan. PRIVATIZATION PROCESSES AND THE CURRENT STATE OF THE REGIONAL SECURITIES MARKET OF NAMANGAN REGION 469-473 p Volume: 6 | Issue: 8 | August 2020 ISSN (Online): 2455-3662 EPRA International Journal of Multidisciplinary Research (IJMR) Peer Reviewed Journal || Journal DOI: 10.36713/epra2013 || SJIF Impact Factor: 7.032 ||ISI Value: 1.188 EPRA IJMR | www.eprajournals.com | Journal DOI URL: https://doi.org/10.36713/epra2013

8. Kadirova Khadicha Turaevna Candidate of Economic Sciences, Associate Professor, Department of Economics and Organization of Industrial Production, Namangan Institute of Engineering and Technology, Namangan, Uzbekistan Development of the Government Securities Market in Uzbekistan 1390-1394p International Journal of Trend in Scientific Research and Development (IJTSRD)Volume 4 Issue 5, July-August 2020 International Journal of Trend in Scientific Research and Development (IJTSRD) @ www.ijtsrd.com eISSN: 2456-6470

9. .Kadirova X.T. Conceptual foundations for the development of the financial market of Uzbekistan pechat Namangan: "ARZHUMAND MEDIA" 2020g. 13.7 pp.

10. Mahmudov Mirabbos FazlitdinovichPhD Deputy Director for General Affairs of the Research Center "Scientific Basis andProblems of Economic Development of Uzbekistan" at the Tashkent State University of EconomicsKadirova Khadicha Turaevna,Candidate of Economic Sciences, Associate Professor of the Department of Economics andOrganization of Industrial Production of the Namangan Institute of Engineering andTechnology.Bustonov Mansurjon MardonakulovichPhD of Department "Organizing the economy and manufacture in industry enterprises" IMPROVING ECONOMIC MECHANISMS TO ENCOURAGE THE EFFICIENT USE OF INDUSTRIAL PRODUCTION POTENTIAL/.1808-1882 p European Journal of Molecular \& Clinical MedicineISSN 2515-8260 Volume 07, Issue 09, 2020 .https://ejmcm.com/?_action=article\&keywords=Bustonov+Mansurjon+Mardonakulovich )European Journal of Molecular \& Clinical Medicine - Articles List ejmcm,ejmcm.com,ejmcm.org,Scopus,Publication,Medical Journal,Fast Publication,Fast Track Publication,Open Access Journal,Elsevier Journal,Free Scopus Journal. 